\title{
Sønderjyder i \\ Finlands indbyrdeskrig
}

\author{
af SøREN SØRENSEN
}

Historien om de cirka 30.000 sønderjyder, som blev udskrevet til tysk krigsdeltagelse i 1. verdenskrig, er velkendt. Langt mindre kendt er det at danske sønderjyder også deltog på tysk side i den finlandske borgerkrig 1918. Forfatteren Søren Sørensen, Vedbæk, som har skrevet flere bøger om Nordens historie og om finlandske forhold, fortæller her om tre sønderjyder ved fronterne i Finland. Til Alfred Good's Fond, som har ydet statte til artiklens publicering, rettes en varm tak.

I bogen Slesvig og Holsten efter 1830, som er andet bind i supplementet til Politikens Danmarkshistorie 1982, omtaler professor Lorenz Rerup uddannelsen af finlandske frivillige $i$ lejren ved Lockstedt $i$ omegnen af Itzehoe fra februar $1915 \mathrm{og}$ fremefter. Uden at antallet angives, kaldes styrken kimen til den finske ${ }^{1}$ hær, og det nævnes at de fleste generaler i Finland havde indledt deres militære karriere som jægere i Lockstedt. Dette forhold, nemlig at de prøjsiske myndigheder accepterede at varetage den militære uddannelse af frivillige unge mænd fra Finland, beskrives af Rerup som et stykke nordisk historie i landet. ${ }^{2}$

\section{Den finlandske frihedsbevægelse og den tyske krigsledelse}

De prøjsiske myndigheders interesse $i$ sagen havde sin helt særlige forklaring. I 1809 blev Finland udskilt af det svenske rige, og den russiske tsar omdannede det til et storfyrstendømme med sig selv som regent. Det fik imidlertid samtidig garanti på at kunne beholde den nedarvede svenske lovgivning, svensk regeringssprog, og det blev styret af landets egne borgere. Den harmoniske udvikling i forholdet mellem Finland og Rusland blev dog brudt i 1890'erne; under indtryk af den tyske oprustning under kejser Wilhelm forlangte den russiske generalstab mere effektiv kontrol over finlandsk territorium. Derfor søgte regeringen i Sankt Petersborg at indskrænke det fin- 
landske selvstyre, men mødte modstand fra en så godt som samlet befolkning. En udbredt værnepligtsstrejke bevirkede at værnepligten blev ophævet i 1904, og de følgende ungdomsårgange modtog derfor ingen militær uddannelse. Det var dette forhold der gjorde det nødvendigt for de frivillige at søge til Tyskland i 1915.

Selv om en række officerer af finlandsk afstamning loyalt udførte tjeneste $i$ de kejserlige styrker, ikke mindst i flåden, og selv om et antal i 1914 meldte sig under de russiske faner som frivillige, og selv om stemningen i ikke ringe grad var ententevenlig, så måtte de russiske krigsmål opleves som fjendtlige. For flertallet af de politisk bevidste stod det klart at man måtte håbe på tysk sejr. Få kunne være $\mathrm{i}$ tvivl om at den russiske statsledelse havde både agt og magt til at indlemme storfyrstendømmet $\mathrm{i}$ kejserriget og sætte dets indre selvstyre ud af kraft.

På denne baggrund opstod der i studenterkredse i Helsingfors den tanke at søge til udlandet for at skaffe sig de nødvendige forudsætninger for at føre en befrielseskrig til sejr. Især i akademiske kredse var der en stærk tradition for tyskorientering, så det måtte da blive Tyskland. Op imod 1500 unge sneg sig ud af Finland, kom som strandede søfolk eller på en eller anden tredje måde $i$ forbindelse med uddannelseslejren i Lockstedt.

For politikerne gjaldt det om at opnå kontakt med politiske organer i Tyskland med henblik på diplomatisk og politisk støtte for Finlands selvstændighed, for studenteraktivisterne at få organiseret en militær uddannelse til brug for en egentlig befrielseskrig.

I første omgang optog aktivisterne ganske vist kontakt med rigssvenske myndigheder; da det ikke gav det ønskede resultat, til danske, ligeledes uden held. Altså blev det Tyskland der gik ind på at uddanne finlandske frivillige til indsats i tilfælde af en tysk invasion over finlandsk territorium. I 1916 blev bataljonen indsat på fronten gennem Letland hvor den vandt betydelig krigserfaring.

Parallelt hermed var der politiske konsultationer. Fremtrædende politikere rejste ud af landet og tog til Berlin for at forhandle med tyske talsmænd. Den tyske krigsledelse havde forinden og samtidigt gjort sig overvejelser også angående Finland. Særligt interessant var sikringen af malmtilførslerne fra de nordsvenske lejer gennem Østersøen, og dermed kontrollen over Åland. ${ }^{3}$ Vigtigt var det desuden at blokere for en britisk landgang ved Murmansk og fremtrængen gennem Russisk Karelen til Petrograd. 
Historikerne har med vægt fort dokumentation for at det tyske engagement alt overvejende beroede på tysk egeninteresse. ${ }^{4} \mathrm{Bl}$.a. er det påvist at den krigsøkonomiske ledelse på ingen måde var blind for de muligheder der lå $\mathrm{i}$ det finlandske produktionsapparat - nu de oversøiske kolonier var gået tabt.

Ved et møde $\mathrm{i}$ kronrådet $\mathrm{i}$ august 1917 tog generalkvartermester Ludendorff spørgsmålet om Finland op. Nogen tid derefter fik de finlandske repræsentanter i Berlin af Ludendorff opfordring til at erklære landet selvstændigt, mens regeringskredse i Helsingfors til gengæld ivrede for at få tysk militær bistand straks for at få de store russiske garnisoner afvæbnet. Ved det midlertidige sammenbrud i våbenstilstandsforhandlingerne i Brest-Litovsk i de første måneder af 1918 blev den gensidige interesse i tysk intervention genopfrisket, og Ludendorff foreslog derfor at finlænderne gentog anmodningen om militær bistand.

Den rent borgerlige regering erklærede Finland selvstændigt den 6. december 1917. Den stod imidlertid med det problem at den ikke havde nogen ordensmagt at støtte sig til. Det tsaristiske politi var af forståelige årsager blevet opløst i marts, så nogen politistyrke fandtes ikke. De russiske garnisoner var naturligvis uanvendelige. I januar 1918 vedtog man så at oprette en national væbnet styrke til bl.a. at afvæbne og hjemsende de russiske styrker, sikre lagrene af brændsel og fødevarer. Til at organisere en sådan milits ansatte man den hjemvendte general C.G.E. Mannerheim, en finlandsk friherre der med held og dygtighed havde ledet en russisk division ved den rumænske front.

Oprettelsen af en sådan regeringsstyrke provokerede $\mathrm{i}$ den grad den organiserede arbejderbevægelse at den overalt $i$ byerne og mange steder på landet tog magten, dels for at sikre at arbejderbefolkningen også fik del i de sparsomme leverancer af levnedsmidler og brændsel, dels for at modvirke at landet blev trukket ind i verdenskrigen. Socialdemokratiet dannede et "folkekommissariat « i Helsingfors som en rød modregering.

Dermed var indbyrdeskrigen en kendsgerning. Den lovlige regering sikrede sig kontrollen med landets nordlige og østlige dele, mens arbejderbevægelsen herskede $\mathrm{i}$ den befolkningstætteste sydlige og sydvestlige del. Fronten strakte sig fra Bottenhavets kyst nord for Bjørneborg til midt gennem det Karelske Næs. Den borgerlige regering var dermed stillet over for det dobbelte problem at den skulle 


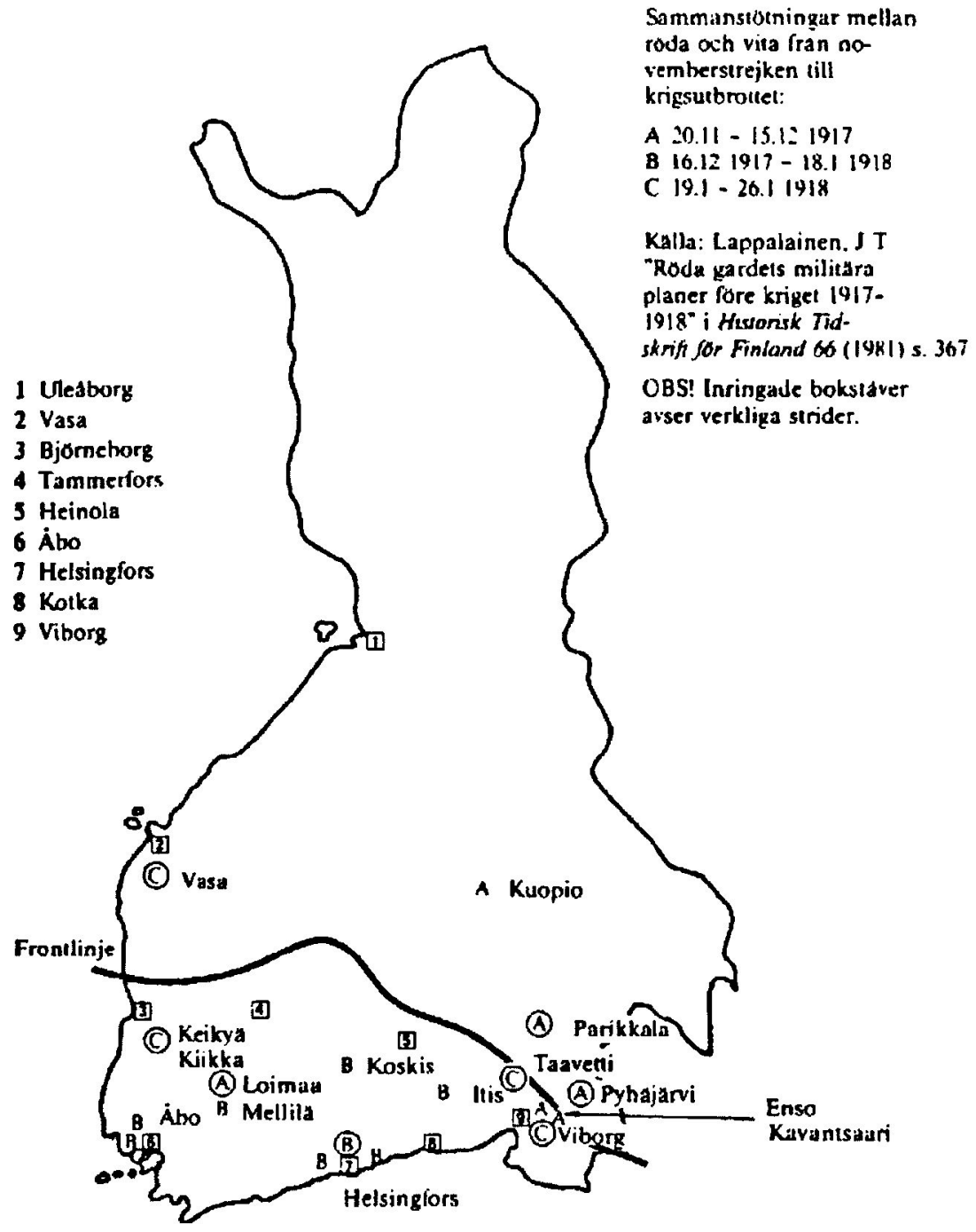

Finland ved krigsudbruddet januar-februar 1918.

slås med landsmænd $\mathrm{i}$ arbejderbevægelsens væbnede røde garder og afvæbne og hjemsende de russiske garnisoner. I marts var de hvide klar til at indgå en egentlig alliancepagt der i realiteten gjorde Finland til en tysk vasalstat.

Grundstammen i regeringsstyrkerne udgjordes af hjemmeværns- 
afdelinger fra land- og bykommuner i de regeringskontrollerede områder. En del officerer der ligesom Mannerheim selv var vendt hjem fra de russiske fronter, enkelte aktivister fra jægerbevægelsen og en del ældre instruktører fra den finlandske værnepligtshær fra før 1899 var hvad Mannerheim kunne disponere over i første omgang. Derfor ivrede han for at $\mathbf{i}$ første omgang svenske officerer burde melde sig som frivillige, i næste omgang danske og norske.

\section{Opinionen i Danmark}

Fra Danmark deltog i alt 7 frivillige på de hvides side under opgøret om Finlands fremtid. De rigsdanske frivillige har fremhævet deres nationale og nordiske sindelag som den væsentlige baggrund for deres engagement, ${ }^{5}$ en af dem nævner udtrykkeligt at hans deltagelse skal ses som et afdrag på taknemmelighedsgælden til Finland for de frivillige finlænderes indsats bl.a. ved Dybbøl i $1864 . .^{6}$ Ellers var de som nationalt sindede stærkt antityske, så det ville måske have været en lettelse for dem at vide at der blandt medkæmperne $i$ arvefjendens uniform også var landsmænd og meningsfæller fra Nordslesvig. Efter kilder at dømme har de nemlig ikke været opmærksomme på at den mulighed forelå.

Interessen i Danmark var utvivlsomt allerede fra begyndelsen af 1800-tallet blevet væsentligt styrket af Finlands stilling som autonomt storfyrstendømme under Danmarks store allierede, Rusland. Kejserinde Dagmars varme følelser for denne del af imperiet kunne heller ikke undgå at have afsmittende virkning i hendes hjemland langt ind i 1. verdenskrig.

Da den russiske militærledelse under indtryk af Tysklands flådeoprustning gennem 1890'erne søgte at forstærke kontrollen over Finland, udløste det velartikulerede protester overalt i den civiliserede verden; en europæisk delegation, overvejende sammensat af videnskabsmænd og med deltagelse af den danske læge C. Normann-Hansen, tog til Sankt Petersborg for at forsøge at bevæge tsaren til at respektere selvstyreordningen for Finland. Tilsvarende gjorde ledende finlandske politikere brug af deres danske kontakter for om muligt at påvirke tsarstyret ad den vej.

Også i Norge tog man livligt del i Finlands skæbne; digteren Bjørnstjerne Bjørnson hvis betydning for Sønderjyllands forhold er velkendt, engagerede sig således også stærkt i finlændernes ret til selvbe- 
stemmelse, noget der naturligvis også havde indflydelse i den danske offentlighed. Danske dagblade og tidsskrifter bidrog ivrigt til at give danske læsere indblik $i$ forholdene derovre, og derfra spredtes informationerne gennem den dansksprogede presse i Nordslesvig til dennes læsere.

Under udviklingen af folkeoplysningen især i den finsksprogede del af befolkningen spillede den danske folkehøjskoletanke en stor rolle, og med den de grundtvigske ideer om sammenhængen mellem personlig og national identitet. Det er blandt sagkyndige en ikke usædvanlig opfattelse at Grundtvigs tænkning få steder har vundet større genklang end netop i finske højskolekredse.

Verdenskrigen ændrede betingelserne for denne gensidige sympati. Desto tydeligere de borgerlige finlandske politikeres tyskorientering trådte frem, desto mere svækkedes med- og samhørighedsfølelsen $\mathrm{i}$ de tilsvarende kredse i kongeriget. Det kom skarpest til udtryk i hovedstyrelsen for Dansk Røde Kors, men det dækkede en udbredt opfattelse.

Når derfor den finlandske regering knyttede sig og landet så snævert til Tyskland og dets økonomiske og militære interesser $\mathrm{i}$ vinteren 1918, måtte mange danskere tage afstand derfra. Ledende medlemmer af hovedstyrelsen for Dansk Røde Kors trådte ud som følge af striden om hvor vidt der skulle sendes en ambulance til Finland. En sådan blev nu alligevel udsendt, men opinionen var stærkt splittet. Ifølge avisreferaterne samlede foredrag om Finland imidlertid store tilhørerskarer, og om sympatien for broderfolket var der ikke megen tvivl på det folkelige og følelsesmæssige plan. Det var først når politiske betragtninger kom ind, at usikkerheden opstod.

Dette bidrog til at kun en håndfuld danskere meldte sig til aktiv krigstjeneste $\mathrm{i}$ den hvide hær. I så henseende var indstillingen afgørende anderledes her til lands $i$ forhold til sammenlignelige kredse i Sverige hvor højregrupperne åbenlyst agiterede for tilslutning til Tyskland og deltagelse $\mathrm{i}$ verdenskrigen på dettes side. I øvrigt viser enkelte presseudsagn fra finlandsk side forståelse for Danmarks vanskelige stilling. ${ }^{8}$

\section{Det tyske felttog i Finland og de danske sønderjyder}

Den 27. prøjsiske jægerbataljons finlandske frivillige ankom den 25. februar 1918 til Vasa. Den tyske overkommando havde frigjort dem 
ved at opløse bataljonen, hjemsende mandskabet og overdrage våben og udrustning til private som derpå sørgede for at det hele var til rådighed for styrken, når den ankom til finlandsk havn.

Næste trin i den tyske bistand var så opbygningen af Østersødivisionen. Med hjælpemandskab kom den op på i alt 15.000 mand. Yderligere blev der dannet et detachement til indsættelse øst for Helsingfors; i de sidste måneder af 1917 havde tyskerne sat sig besiddelse af Letland og Estland - erobringen af den tidligere danske ø Øsel havde i december kostet bl.a. sønderjyden Hans Andersen fra $\varnothing$ sterby livet. $^{9}$ Af styrkerne på Tallinnfronten frigjordes et infanteriregiment (nr. 225), $1 / 2$ eskadron af 2 . husarregiment og noget feltartilleri under kommando af oberst von Brandenstein. Invasionsflåden kommanderedes af kontraadmiral Hugo Meurer (Sonderverband Ostsee).

Den 3. april gik den tyske Østersødivision under kommando af general Rüdiger von der Goltz i land ved Hangö. Heri indgik der også soldater fra Sønderjylland. Styrken bestod at den 95. reserveinfanteribrigade, den 3. reservejægerbataljon under major $O$. von der Schulenburg-Lieberose og med $\mathrm{i}$ hvert fald én sønderjyde blandt soldaterne, den 4. jægerbataljon, gardekavalleri og gardeulanregimenter, et saksisk karabinregiment og et bayersk bjergartilleribatteri, maskingeværafdelinger, et cykelkompagni, der interessant nok står under kommando af en løjtnant Lassen. Det er ikke lykkedes at identificere denne som sønderjyde. Hertil kom pionerer, telefonfolk, sanitærer og feltlazaret m.m. De saksiske og bayerske enheder kan vi se bort fra, men i de prøjsiske enheder kunne der være andre sønderjyder end de to vi kender fra tabslisterne.

Gennemgang af den af Poul Harris redigerede fortegnelse »over de til Monumentet i Mindeparken i Aarhus 4.140 indkomne Navne paa de i Verdenskrig 1914-1918 faldne dansksindede Sønderjyder«, indsamlet frem til 1. februar 1932, viser at der heri faktisk optrådte navne på tre sønderjyder der var faldet/omkommet i forbindelse med det tyske felttog i Finland, nemlig Niels Chr. Corneliussen fra Lille Emmerske, Carl Petersen fra Haderslev og Johan Andreas Schmidt fra Broager.

Følger man frontberetningerne $i$ den nordslesvigske presse ${ }^{10}$ fra foråret 1918, kan man se at redaktørerne har været interesseret i udviklingen i Finland; en hovedkilde har de tyske presseagenturer været. Herudover blev der citeret fra kongerigske dagblade, f.eks. også hvad svenske og finlandske pressebureauer har viderebefordret. I al- 
mindelighed var den nordslesvigske presse vel orienteret om udviklingen i Finland. Naturligvis var de relativt kortfattede pressemeddelelser fra øverste hærledelse, Wolffs Bureau eller de svenske og finlandske bureauer via de københavnske dagblade i højeste grad ensidige; hovedsagen er imidlertid at ingen i Nordslesvig i foråret 1918 behøvede at være $\mathrm{i}$ tvivl om at tyske styrker var indviklet $\mathrm{i}$ hårde kampe i Finland.

I nogle hjem, nøjagtigt hvor mange vides ikke, har man så også vidst at der var sønderjyder med i disse kampe.

I første omgang satte tyskerne sig i besiddelse af Åland. Ganske vist var øgruppen allerede besat af svenske styrker, men de modsatte sig på ingen måde den tyske invasion og blev efter nogen tid trukket hjem. Formelt stod de tyske styrker under general Mannerheims overkommando, men han havde ingen fysiske eller tekniske muligheder for at påvirke deres bevægelser. von der Goltz opererede derfor efter den tyske overkommandos planer. Ikke mindst af propagandamæssige hensyn var erobringen af Helsingfors af højeste prioritet.

Efter hovedstyrkens landgang ved Hangö rykkede den frem mod Helsingfors som blev angrebet den 12. april og efter forbitrede kampe, i visse kvarterer fra hus til hus, erobret den 14. von Brandenstein var den 7 . april gået $\mathrm{i}$ land ved Lovisa og rykkede ind i landet $\mathrm{i}$ retning mod Lahtis for at afskære de røde forbindelserne østerud.

Østersødivisionen konsoliderede kontrollen over hovedstaden, og derefter rykkede dens enheder mod nord og mod vest for at slå de store røde styrker dér og om muligt få kontakt med Mannerheims hærafdelinger der trængte frem nordfra. I en række voldsomme slag med betydelige tab for invasionsstyrken blev de røde endeligt slået, og den 5. maj var felttoget i Finland slut for tyskernes vedkommende, et forløb Nordslesvigs avislæsere havde gode muligheder for at følge gennem de officielle frontberetninger og via de forskellige bureauer.

På dette tidspunkt var de indkaldte fra Nordslesvig ramt af to dødsfald. Det ene var ind truffet i forbindelse med erobringen af Helsingfors, den pågældende var blevet hårdt såret allerede under de tidligste skudvekslinger og døde samme dag på lazarettet. Det andet indtraf under minerydning »ved Finlands kyst «, hvorved en overfyrbøder på damperen »Klaus Groth « omkom. En måned efter at kampene var endt, døde endnu en sønderjyde på lazarettet i Sankt Michel (ca. $250 \mathrm{~km}$ nordøst for Helsingfors) efter at være blevet hårdt såret i de afsluttende meget hårde kampe mellem tyskerne og de røde garder. 


\section{Niels Christian Corneliussen, Lille Emmerske}

Om Niels Chr. Corneliussen, født i Lille Emmerske ved Tønder den 18. marts 1883, er det oplyst at han døde den 4 . juni 1918, altså en måned efter krigshandlingernes ophør og, som allerede anført, på militærhospital i Sankt Michel. Han er ikke omtalt på mindebladene der knytter sig til den overvejende del af krigsofrene, og andre oplysninger har det ikke været muligt at få frem. Den daværende tyske præst i Helsingfors Friederich Israeli udgav i 1918 en mindebog over Deutsche Brïder in Finnlands Erde (Hfors 1918), og han ved at fortælle at Corneliussen er druknet, hvor han så har den oplysning fra. Derimod oplyser han ikke hvilken enhed Corneliussen var knyttet til. Ud fra hans alder kan man ikke slutte noget, og stedet for hans død er umiddelbart egnet til at vække undren, idet Sankt Michel ligger ganske langt fra slagmarkerne, ad landevejen flere hundrede kilometer.

Ved erobringen af Tammerfors havde general Mannerheim forlagt sit hovedkvarter til Sankt Michel, som han i øvrigt også anvendte hertil under vinterkrigen 1939-40 og fortsættelseskrigen 1941-44. Her var der derfor ingen tyske forlægninger, idet Østersødivisionen efterfølgende blev forlagt i Viborg og Kouvola, d.v.s. ikke for langt fra grænsen til Sovjetrusland, og med staben i Helsingfors og et uddannelseskommando i Fredrikshamn. ${ }^{11}$

Spekulationer har vist sig overflødige, den tyske præst har åbenbart været fejlunderrettet. Den 8. juni 1918 indrykkede nemlig de efterladte med hustruen Anna $\mathrm{H}$. Corneliussen og hendes to små børn i spidsen en dødsannonce i Flensborg Avis, og heraf fremgår det at han er afgået ved døden efter at være bleven haardt saaret den 30 . april. ${ }^{12}$ I overensstemmelse med hvad der ellers gør sig gældende, angives det hverken hvor han døde, eller hvor han blev såret. ${ }^{13}$ Det er imidlertid bekendt at enheder af den tyske invasionsstyrke i dagene 27.-30. april var indviklet i meget hårde kampe omkring landsbyen Syrjäntaka midt mellem Tavastehus og Lahtis. Selv om det iflg. von der Goltz var det saksiske karabinierregiment der tog hovedstødet der, kan man imidlertid ikke ganske udelukke at Corneliussen kan havde været med her, fordi 3. prøjsiske reservejægerbataljon hørte til den samme brigade.

De tyske tab ved Syrjäntaka var omfattende, næsten en tredjedel af samtlige tyske faldne og sårede under felttoget i Finland skal skrives 
Dedsannoncen for Niels Chr. Corneliussen $i$ Flensborg Avis den 8. juni 1918. Salmeverset er anden strofe af den norske digter W.A. Wexels salme Tænk, naar engang den Taage er forsvunden ( $n r$.

Vi har modtaget dot tunge Budskub, at min kivro Mand, mine to smaa Horns gode 653 i Den danske Salmebog). Fader, min kare san og sivigersan, min onesto Broder, Svoger or Onkel

lidels Cit. Conneinss?

er argaaet ved Doden don 5. Juni efter at vare $b$ even laaldt saaret den 30. April, 30 Aur gamme.

$$
\text { I dyb Sorg: }
$$

Anna H. Corneliussen og Born Anna og Magdaiena, P. Corneliussen,

Christlan Jordt og Hustru, Anton Cornel.ussen, findt Tott, f. T. i Felten, Familien Jordt og Familien Christ ansen, Lille Emmersko.

Vester Elujsted, d. B. Juni 1918. Tæuk, naar engalig or lest brei .ordixk Gando. besvaret hrert "Hvorfo" jex giunder paa.

mesi kunde oj mied al min Giubion iarde.

Tenk, naar ioj Heirens Dojo skn. kiart lorstua.

Fergegudat. onussiall Pul blive jukeudajoldi sentelo.

på Syrjäntakaslagets konto, og slaget her er fra begge sider, både den røde og den tyske, blevet karakteriseret som det mest rasende under hele krigen. von der Goltz hævder i sine Krigsminnen 1920 at så kraftigt 
ville næppe franskmændene være gået til angreb som disse fanatiske tilhængere af barbariets nye evangelium. ${ }^{14}$

Hvorledes de to oplysninger, den tyske præsts om druknedøden og familiens om sårskaderne, $i$ givet fald kunne forenes, er det meningsløst at spekulere i. I slaget ved Syrjäntaka forsøgte tyskerne at undslippe de rødes kanon- og maskingeværild ved at svømme over en af de tusind søer, men uden journalen fra lazarettet kan der ikke siges noget herom.

\section{Carl Petersen, Haderslev}

Han vides at være født 13. september 1875 (iflg. andre kilder 19. marts) og at være omkommet den 18. april 1918 "ved den finske kyst«. På dette tidspunkt var han som ovenfor anført overfyrbøder på skibet »Claus Groth« hvorfra også andre søfolk ved samme lejlighed mistede livet.

Carl Petersen er født i Haderslev og figurerer derfor på lægdsrullen fra Gl. Haderslev sogn, men vel at mærke den over statsløse. Det bemærkes i den pågældende stamrulle, dateret 1916, at han er vor Jahren mit den Eltern nach Dänemark verzogen. Imidlertid må han altså være vendt tilbage til tysk territorium og er blevet forhyret på damperen „Claus Groth«.

Pastor F. Israeli nævner hans navn og stilling i Deutsche Brüder uden tilsyneladende at vide at han altså faktisk er dansk - men heller ikke mere. Hans navn optræeder ikke i den fortegnelse til monumentet i Århus der er afsluttet i efteråret 1931, først i den afsluttende fra februar 1932, og der findes heller ikke noget mindeblad i landsarkivet der kunne hjælpe os til forståelse af hans færden mellem stamrullen 1916 og dødsfaldet to år senere.

"Claus Groth" var som fiskeridamper inddraget til tjeneste i kontreadmiral Meurers Sonderverband, nærmere betegnet i den 9. minesøgerhalvflotille. I denne egenskab deltog damperen i minerydningen før landgangen på Åland, og ligeledes var den med til at etablere en minefri sejlrende fra Libau på Letlands vestkyst til Hangö på Finlands sydkyst. I de følgende uger blev halvflotille 9 sat til at udvide og sikre sejlrenden frem til Helsingfors som tyskerne havde erobret den 14 . april. Den 18. løb "Claus Groth « på en mine 101/2 sømil nordvest for den nordligste spids af Dagø; fartøjet ramtes lige under maskinrummet, og fyrbøderne gik til ved eksplosionen. 


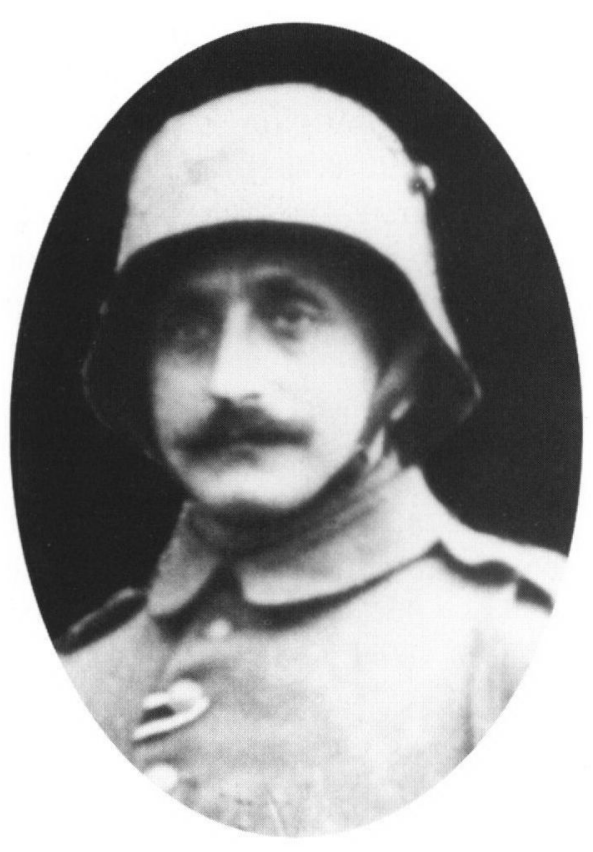

Joh.Andr. Schmidt, Broager, født 28. maj 1885, dod 12. april 1918 på lazaret $i$ Helsingfors. Foto $i$ Museet på Sønderborg Slot.

\section{Johan Andreas Schmidt, Broager}

Mest har det været været muligt at finde vedrørende jægeren Johan Andreas Schmidt, født den 28. maj 1885 og død den 12. april 1918. Den 3. juli 1912 blev han nemlig gift i Broager kirke med Dora Andresen fra Sønderborg, og hans dåbsattest har da vist at han er født uden for ægteskab i Kgr. Bayern, landsbyen Leonrod, af en vis Anna Schmidt. Hans borgerlige erhverv var slagter. Nogle måneder før brylluppet var han flyttet fra Nordborg til Sønderborg, den 12. januar 1913 fødes en søn, og ugedagen efter opgiver Sønderborg Melderegister at familien er flyttet tilbage til Nordborg.

Dér forsvinder så sporene indtil Johan A. Schmidt den 12. april 1918 dør på soldaterlazarettet $\mathrm{i}$ Helsingfors som følge af skudsår $\mathrm{i}$ forbindelse med stormen på byen; da er han soldat i 3. prøjsiske reservejægerbataljon. Samlingen på Sønderborg Slot har et soldaterbillede af ham hvorpå der står at han er hjemmehørende i Broager. Der findes intet mindeblad over ham i landsarkivets samling, men inden 1. februar 1932 er han blevet tilmeldt monumentet i Århus og dermed erklæret dansksindet - trods det bayerske fødested. 


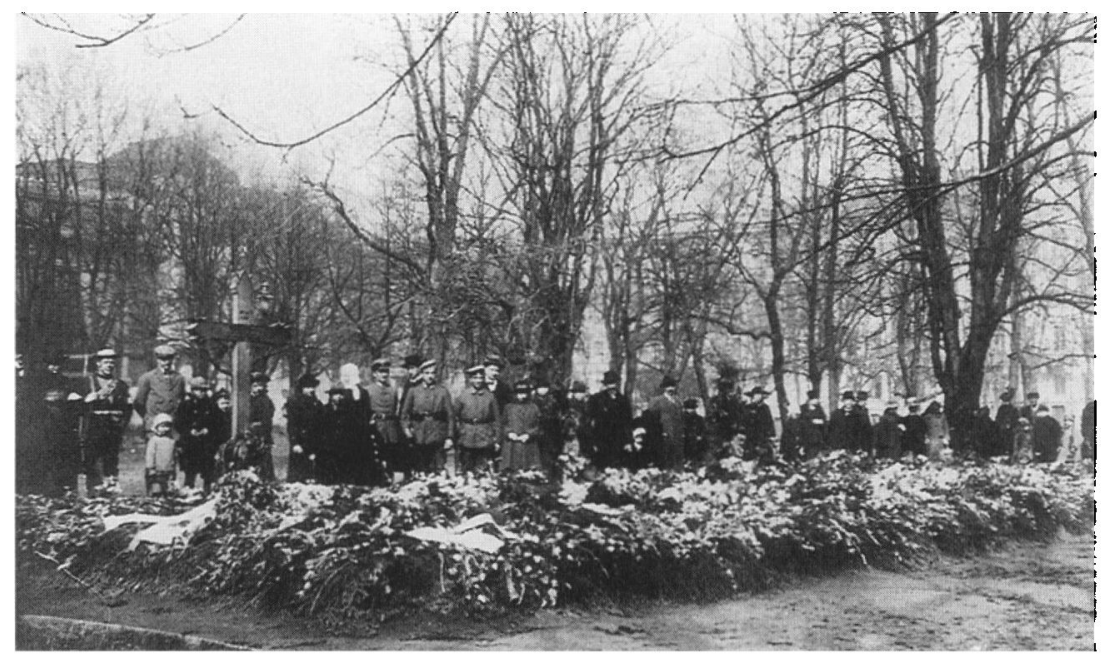

Begravelsen af de tyske faldne i parken ved Helsingfors' gamle kirke. Billede i Krigsmuseet Helsingfors. Gengivet efter R. Arimo: Saksalaisten sotilaallinen toiminta Suomessa 1918 (1991).

Men da har hans navn allerede i mange år stået indhugget på en anden mindesten. På den gamle kirkegård i Helsingfors - som man har udsigt over fra den danske ambassadørs stuevinduer - blev der i 1918 rejst et stort monument over de tyske krigergrave fra stormen på byen. Begravelsen fandt sted allerede den 16. april, og Fr. Israeli refererer udførligt alle talerne ved den lejlighed. ${ }^{15}$ Jægeren Johan Schmidt er nævnt, og hidtil har ingen vidst at han regnedes som hørende til danskheden på Sønderborgegnen.

Schmidt var slagter, Petersen søfyrbøder, begge var arbejdere; om de var socialdemokrater som de finlandske modstandere de sloges med, var det, vides ikke, men selv general von der Goltz fremhævede at mange af hans soldater var det. ${ }^{16}$ Desuagtet var indbyrdeskrigen $i$ Finland en ren klassekrig, og efter arbejderbevægelsens nederlag var klassetilhørsforholdet tilstrækkeligt som grundlag for arrestation, anbringelse i koncentrationslejr eller summarisk henrettelse. Tyske og danske arbejdere bidrog til det nederlag deres finlandske kammerater led, historiens ironi antager mange former. 


\section{Sønderjylland og Finland}

I 1918 deltog danskere fra begge sider af Kongeågrænsen i kampene i Finland; på grund af indbyrdeskrigens karakter af et politisk og socialt væbnet opgør mellem forskellige samfundsklasser kan man ikke sige at de syv kongerigske officerer eller det ukendte antal nordslesvigske soldater og søfolk kæmpede for Finlands sag; de kæmpede for opretholdelsen af en bestemt politisk orden og på kort sigt for at styrke den tyske krigsmaskine i det globale opgør om herredømmet.

Anderledes forholdt det sig i 1939-40 da danske frivillige i hundredtal meldte sig til indsats $i$ Vinterkrigen. Kun de frivillige i flyvevåbnet nåede at komme i kamp, og af de danske flyvere satte mange livet til for Finlands frihed. Under vinterkrigen var det nemlig en enig nation der modsatte sig det sovjetiske angreb. Det var en anden situation.

I den finlandske debat op til verdenskrigen spillede sønderjyderne en rolle; det kan tænkes at have haft en vis sammenhæng med at finskhedsbevægelsen ${ }^{17}$ var påvirket af Grundtvigs ideer om folkelighed og folkeoplysning, men faktisk er det ikke nødvendigt at forudsætte noget sådant; dertil er paralleliteten for iøjnefaldende. Den senere så betydningsfulde finlandske statsmand, J.K. Paasikivi, var allerede $\mathrm{i}$ det forste årti af 1900-tallet en fremtrædende politiker inden for den ideologi man betegner som eftergivenhedspolitikken, og han så ligheden mellem denne og de danske sønderjyders legalitetspolitik over for den prøjsiske stat.

Omvendt var H.P. Hanssen-Nørremølle for sit vedkommende fyldt af forståelse for strømningerne i Finland. Han udtalte i 1902 bl.a. følgende:

Forfatningsbrudet $i$ Finland indleder et nyt Afsnit af en Nationalitetskamp, som er ført under skiftende Former, saa langt vor Viden rækker tilbage. Knuget af Sorg og afmægtig Harme, blændet af det forste voldsomme Slags Smerte, er det finske Folk nu ført ind paa det Udviklingstrin, vi Nordslesvigere maatte gennemgaa $i$ de forste Aar efter Ulykkesaaret $1864 .{ }^{18}$

Ved folkemødet den 17. november 1918 på »Folkehjem « i Åbenrå opregnede H.P. Hanssen i sin tale ${ }^{19}$ de pladser der rummede sønderjydernes grave: Spredt ud over Landene ligger nu vore faldne Brødres Grave. De findes $i$ Ruslands susende Naaletræsskove og vidtstrakte Sumpe, langs Polens Floder og i Serbiens Dale, i Argonnerne og Karpaterne, i Makedonien og ved Dardanellerne, i Palæstina og Mesopotamien. Han nævner 
ikke stadskirkegården i Helsingfors eller heltekirkegården i Sankt Michel. Det er da heller ikke i tal noget der er værd at sammenligne med Ruslands susende Naaletræsskove og vidtstrakte Sumpe. Det drejer sig blot om tre faldne, en sømand, rettere: en søfyrbøder på et minerydningsfartøj, en jæger i Reservejægerregimentets 3 . bataljon, og endnu en soldat om hvis tilhørsforhold de undersøgte kilder tier. Hverken i forhold til det samlede antal dansksindede sønderjyder der sammenlagt omkom under 1 . verdenskrig, eller i forhold til de samlede tyske tab ved felttoget i Finland i 1918, er det noget iøjnefaldende tal. Men der var faldne, og det er hovedsagen.

\section{NOTER}

1. Uvist af hvilken grund anvendte Rerup dette ukorrekte udtryk; idet finsk alene angiver hvad der tilhører sproggruppen, de finsktalende, anvendes der $\mathbf{i}$ overensstemmelse med sprognæunets anbefalinger $i$ denne tekst som nationalitetsbetegnelse finlandsk.

2. Op.cit. p. 305.

3. Den tyske Finlandspolitik er udforsket af bl.a. Osmo Apunen i bogen Suomi keisarillisen Saksan politiikassa 1914-1915 Hki 1968, Yrjö Nurmio i Suomen itsenäistyminen ja Saksa Hki 1957 og Hannu Rautkallio i Kaupanteko Suomen itsenäisyydellä Hki 1977, hhv. om Finlands rolle $i$ Kejsertysklands politik 1914-1915, Finlands selvstændighed og Tyskland og Købslåen om Finlands selvstændighed.

4. Jvf. især Hannu Rautkallio: Kaupanteko Suomen itsenäisyydellä. Sakskan sodanpäämäarät Suomessa 19171918. Hki 1977.

5. Se f.eks. min artikel i Krigshistorisk Tidsskrift nr. 3/1995.

6. Nemlig Peter de Hemmer Gudme i forordet til bogen Finland Nordens Østvold Kbh 1940.

7. Et forhold der bl.a. understregedes ved et livligt finsk engagement i 200 års fejringen af Grundtvigs fødselsdag i 1983.

8. Den finsksprogede konservative Hel- singforsavis Uusi Päivä juni 1918 (iflg. Dybbøl-Posten af 27.6.1918).

9. HA, født 27.2.1896, faldet på Øsel 29.12.1917, jvf. opl. i Poul Harris 19141918 Monumentet i Århus. Optegnelserne dateret 1.2.1932. Mindeblad for HA savnes.

10. D.v.s. i denne sammenhæng Flensborg Avis, Dybbøl-Posten og Modersmaalet.

11. Jvf. R. Arimo Saksalaisten sotilaallinen toiminta Suomessa 1918 Rovaniemi 1991 p. 94.

12. Flensborg Avis 8.6.1918.

13. I Dybbøl-Posten af 18.6. omtales han som faldet i Frankrig, men da ovrige kilder er enige om Finland, holder jeg jeg mig til det. Det kan ikke afvises, det er endog sandsynligt at der eksisterer et Sankt Michel i Frankrig, men heller ikke at en journalist i Sønderborg der har vidst at kampene i Finland var ophert, har antaget det katolsk klingende stednavn som værende fransk.

14. I oversættelse efter den svenske oversættelse Hfors 1920 p. 110.

15. Deutsche Brüder p. 38ff.

16. Krigsminnen p. 103: Därför lät jag även förklara för redaktören for den socialdemokratiske tidningen, att vi ingalunda förde krig mot hans parti, $i$ vara led kämpade t.o.m. många socialdemokrater. 
17. D.v.s. den bevægelse der agiterede for en afsvenskning og for fremme af det finske sprog i Finland; formålet var primært dermed at forhindre en russificering.

18. Artiklen Nationalitetskampens Ud- vikling (1902). H.P. Hanssen: Fra Kampaarene Afhandlinger og Foredrag Kbh 1929 II p. 58.

19. Her efter Franz von Jessen: Haandbog II 1938 p. 40 med dagbladet Hejmdals referat som kilde. 